\title{
Comparability of Limitation, Deprivation and Termination of Parental Responsibility in Kosovo and in Some Balkans States
}

\author{
Burim Tahiri, PhD
}

Kosovo

\begin{abstract}
The parental right shall regulate the relationships between parents and children as well as other persons of kin. The characteristics of this right shall be the various elements which are very important in accomplishment of relations between parents and children. In this paper we will be focused on limitation, deprivation and termination of parental responsibility. Even that the importance of elements comprising the parental responsibility is undisputed, our focus has derived as a consequence of the importance and sensitivity that these elements have in contrary to the other elements comprising the parental right. Limitation of the parental responsibility comes due to the abuse of children by their parents. In such cases the parents shall be limited to parental responsibility to that time limit such a situation lasts. Deprivation of parental responsibility may come as a consequence of parents, behaviors from which the personality or property of the children is at a high danger. Parents with such behaviors that endanger seriously the personality or property of children shall be deprived from the parental responsibility. Termination of parental responsibility happens in certain cases based on which the parents shall not be any more responsible for their children after there have been fulfilled the conditions foreseen by the Law. With the positive legislations of some countries included in this paper there have been determined expressively the cases of termination of parental responsibility. It is important to mention that not all countries have determined, in their Laws, the matter of termination of parental responsibility that makes the discussion of this paper more distinctive.
\end{abstract}

Keywords: Parental responsibility, right, parent, child, limitation, deprivation, termination

\section{Introduction}

The parental right shall be an important part of judicial system in Kosovo. Hence, we have decided to treat this matter.

Study object of this paper shall be the limitation, deprivation and termination of parental responsibility. Moreover, a special attention will be given to the causes of limitation of parental responsibility from which there shall be noticed the cause this responsibility may be limited from. Furthermore, attention will be given even to the causes based on which the parental responsibility shall be deprived, as well as rights and duties of parents during the period of deprivation of parental responsibility. A detailed treatment will be over the cases of termination of parental responsibility.

The purpose of treatment of these elements, between the legislation of Kosovo and legislations of some Balkans countries shall be the identification of similarities and differences between the positive legislation in Kosovo and legislations of the above mentioned countries.

\section{Limitation of Parental Right}

The parental right may be limited if the parents behave without responsibility, abuse the parental right, endanger the personality, rights and interests of children.

Exercise of parental right should always be done in the interest of the child, but there is not always respected such a rule by the parents. In various cases, parents may act in that manner that will violate the general interest of children and endanger their welfare. State institutions should undertake all measures of protecting the children's interest and in such circumstances they should interfere proportionally in the created situation. Convention on the Rights of the Child determines the obligation of the state to undertake all legislative, administrative, social and educational measures for protection of the child in any form of physical or mental violation, insult or mistreatment, during the time he/she is under the custody of his/her parents or legal representative or any trusted persons ( $\mathrm{CRCH}, 19)$. In Kosovo, the custodian body shall be obliged to 
supervise the exercise of the parental rights and obligations. In cases when this body ascertains that there has been endangered the interest of child due to the abuse of parental right, or any danger to the child due to serious negligence of parental obligations, it shall be obliged to undertake urgent measures for protection of the child's personality, rights and interests (FLK, 147, Gashi\&Aliu\&Vokshi, 2012, 341). The matter of limitation of the parental right is regulated even by the Family Law in Serbia. However, unlike Kosovo Law, the Family Law in Serbia (79) determines more in details the supervision of the parental right by the custodian body, since there have been determined the prevention and correction actions regarding the exercise of parental right by custodian body. Supervision of the exercise of parental right by the Custodian Body, as in Kosovo, is conducted even in Montenegro, since Montenegro by Family Law (80) has determined similarly the competence of the Custodian Body to supervision of exercise of parental right. However, Croatia in the exercise of supervision of this right differs from Kosovo, Montenegro and Serbia. Family Law in Croatia (109) determines that the competent body to exercise the supervision of parental care shall be the Social Welfare Centre. Furthermore, unlike the above mentioned countries, Croatia, by this Law, has determined even the prevention and correction measures regarding the supervision of parental care.

Based on the comparative research regarding the exercise of supervision of parental care, it is proved that Kosovo, Croatia, Serbia and Montenegro have regulated institutionally the exercise of supervision of parental care.

It is important to emphasize that Albania has not determined the competence of the Institution on supervision of parental care which may be considered as a gap of Albanian legislation in regulating this matter.

If from the supervision of exercise of parental care by the respective institutions there is ascertained that the parental rights have been exercised and continue to be exercised in the damage to the child's interest then there shall be initiated the procedure at the court in order that the court shall, by a decision, limit the parents to exercise the parental rights and obligations, when there is ascertained that this will impact positively the interest of children (Podvorica, 2006, 192). Limitation or deprivation of the parental right may come into consideration in case the parents express negligence in the care of their children, as well as when they do not prohibit their child in conducting bad actions which will damage him/her seriously (Garber, 2010, 216).

There are two types of parents' rights and obligations for children that may be limited

a) Limitation of the rights and obligations against the personality of the child, b) Limitation of the rights and obligations against the property of the children (Podvorica, 2006, 192).

A) Limitation of the rights and obligations against the personality of the child - shall mean the limitation of those rights exclusively related to the personality of the child. With this kind of limitation of the rights, the parents are limited only to the rights related to the personality of the children but not the rights related to the property of the children (Podvorica, 2006, 192). In the case when there is ascertained that there is impinged the personality of the child, the custodian body shall undertake these measures with the purpose of avoiding the created situations that cause danger for children: a) giving remarks to the parents, b) continuous supervision of the exercise of parental right, c) taking away the child from the parent (Aliu \& Gashi, 2007, 236).

B) Limitation of the rights and obligation towards the property of the children

Unlike the first case when then the rights of parents shall be limited only to the personality of the child, in the second case we have to do with the limitation of the rights of parents toward the property of their children. In such cases the parents shall be limited to the rights related to the property of their children due to mismanagement of the property of the children. Limitation of these rights may be done to one or to both parents. Kosovo, has regulated, by the Family Law (134), the matter of care for the property of the children by their parents as well has it has determined that parents should administer the property of their children in the right way. If there comes a point of misuse of the property of the children then the competent bodies shall take measures by which there shall be limited the rights of the parents towards the property of their children. Custodian Body or court may require from the parent to report regarding the administration of the property of the children, require that there shall be permitted the insurance means for the property of the parent from the court, require that the parent, in the aspect of administrating the property of the child, to be equalized with the position of custodian that means the parent shall be obliged only to administer the property of the child (Podvorica, 2006, 195). All these cases have been determined by the lawmaker with the purpose of establishment of legal security regarding the personality and property of the children as the most sensible part of society. 


\section{Causes of Limitation of the Parental Right}

Causes of limitation of the parental right shall be those circumstances, the existence of which causes the limitation of the parental right.

Limitation of parental right may be conducted by the competent bodies in those cases when there is impinged or damaged the interest of the child. Limitation of this right may be done only in certain cases when the undertaking of actions is necessary for the welfare of the children and when the interest of the children requires so.

Causes which may lead to the limitation of the parental right may be of various kinds. There are causes that may lead to the limitation of the parental right towards personality of the child and causes which may lead to the limitation of the parental right towards to the property of the child. Causes, the existence of which leads to the limitation of the rights and obligations of the parents towards personality of the children, shall be actions that endanger and damage the personality of the children and for this reason there shall be taken measures by which there are avoided such actions that are not in favour of the general interest of the child. Convention on the Rights of the Child has determined the obligation on the undertaking of all measures on protection of the child from every form of physical and mental violation, insult or ill-treatment, abandonment or negligence; actions which have a negative impact to the personality of the child, during the period of time he/she is under the care of his/her parents or one of his/her parents, legal representative or trusted person $(\mathrm{CRCH}, 19)$. Hence, according to this Convention the causes that may limit the exercise of the parental right towards the personality of the child shall be the physical and mental violence, insult and ill-treatment of the child as well as other actions. Kosovo has, as well, determined that when there is ascertained that there has been endangered the interest of the child due to abuse of the parental right, or any danger for the child, the Custodian Body should, with the purpose of avoiding such situations, undertake urgent measures for the protection of the personality, rights and interests of the child (FLK, 147, Gashi\&Aliu\&Vokshi, 2012, 341). In such cases, causes shall be considered parents' actions or non-actions from which there is damaged or endangered the personality and property of the children. Parents, by their actions, except the danger to the personality of their children may endanger or damage even the property of their children.

Moreover, the serious abuse with the children and exercise of violence against them by which there may be caused trauma with serious consequences that may have reflections to children from fear and anxiety experienced by the exercise of the violence by their parents may bring the situation up to the deprivation or limitation of the parental right (Brown \& Alexander, 2007, 39).

In those cases when the actions of the parents are of that kind that cause damages or such actions may damage the property of the children there may happen the limitation of the parental right towards property of the children. Limitation of the parental right towards the property of their children shall be done in those cases when there are causes such as bad administration of the property of their children from which there is the danger and damage to that property. Administration of the property of the children by their parents shall be a right and obligation entitled to them until their children reach the adulthood. There may happen that during the administration of the property, the parents undertake actions that cause damages or endanger the property of the children. These actions are causes, the existence of which makes possible the limitation of the parental right towards the property of the children. Causes may also be actions or non-actions of one or both parents. If only one parent has undertaken such actions, then the parental right shall be limited only towards that parent who through his/her actions has caused damage or has endangered the property of his/her children, while if those actions that have caused damage or have endangered the property of the children have been conducted by both parents, in these cases the limitation of the parental right towards the property of the children shall be done for both parents.

\section{DEPRIVATION OF THE PARENTAL RESPONSIBILITY}

The parental right shall be the right entitled to the parents; that right should be exercised only in favour and interest of children. However, in various cases there can happen that this right is exercised wrongly from which there will be seriously damaged or endangered the interests of children. Deprivation of parental right shall be the most serious measure that shall be imposed to parents who misuse the rights and obligations towards their children. In cases when parents cause violence against children, there shall be imposed measures which will prohibit parents to approach the victim, in this case children (LPADV, Article 5). Because of the high importance of the protection of children's rights, the deprivation of parental right 
may be done only in cases foreseen by the Law, and for this reason this matter has been regulated in details by a legal framework. In Kosovo, the parental right may be deprived in cases when the parent misuses the parental responsibility or expresses serious carelessness in exercising that right (FLK, 149, Gashi\&Aliu\&Vokshi, 2012, 347). Moreover, similar to Kosovo, this matter is regulated even in Croatia (FLC, 111, 112, 113, 114, 115), Serbia (FLS, 81, 82), Montenegro (FLM, $87,88,89$ ), Albania (FCRA, 228, 229) and Macedonia (LFRM, 90) where there has been expressively emphasized that the parental right may be deprived when the parents misuse or express serious carelessness in the exercise the parental right. The parental right may be deprived by the court with the decision to the parent who does not fulfil the rights and obligations towards his/her children (GCC, Book 1, 1. 266).

Deprivation of the parental right shall be done by the competent court decision when there exist certain reasons foreseen by the Law $(L O C P, 107)$. The court may decide on deprivation of the parental right for one or all children, depending on the infringement of the interests of children. The court shall take the decision when ascertains that the parents have violated or infringed the rights of children, but it is important to mention that there are cases when the court does not take decision towards parents that are not guilty for the outrage of the rights of children, for example the parents that have no ability to act, or parents due to physical disabilities are not able to take care after their children (Begeja, 221, Podvoria, 2006, 197). Even if the court takes a decision by which there is deprived the parental right towards children, that court decision can not dismiss them even from the obligation for the food of children (Begeja, 221). Here we can ascertain that even when parents are deprived from the parental right, they are not deprived from the obligation for the food for their children. Cases for which there can be initiated the procedure for deprivation of parental right, the states of the region have almost the same regulation as this one. However, there are differences at the entities that may initiate the procedure. In Kosovo (FLK, 150.1, Gashi\&Aliu\&Vokshi, 2012,350) the entities that can initiate the procedure for this matter shall be the other parent, custodian body and the court. Even by the Family Law in Serbia, there is determined that the initiation of the procedure for deprivation of the parental right may be carried out by the parent, custodian body and the court. In Albania (FCRA, 228), the initiation of the procedure may be carried out by parent, relatives of the child and prosecutor. However, in Montenegro there is determined the initiation of the procedure on the abovementioned matters may be carried out by the parent, child, social affairs centre and the court upon official duty. While in Croatia, the initiation of the procedure for the deprivation of the parental right may be carried out by the parent, child, social affairs centre and the court upon official duty. From this comparison we can ascertain that this matter is regulated at best by the Family Law in Kosovo and the Family Law in Serbia taking into consideration their legal determination regarding this matter, since we should take into account that such a legal determination shall establish a greater legal security in relation to the concrete case.

Causes of deprivation of parental responsibility

In cases defined by the Law, when the exercise of the parental right is not in the interest of children there may be deprived this right. However, this may be done only for causes determined by the Law. According to Kosovo legislation as cause due to which there may be deprived the parental right shall be: a) misuse of the parental right b) serious violation of parental right (Aliu \& Gashi, 2007, 240).

Misuse of the parental right - shall mean the bad behaviour of parents who ill-treat their children physically and mentally, encourage them to condemn criminal offences that would have material benefit for their parents. Decision of deprivation of the parental right in such circumstances shall be taken by the court in out-contentious procedure. The parental right can not be deprived if there are not causes defined by the Law and if there is not developed a judicial procedure (Aliu \& Gashi, 2007,240 ). For such causes the parental right may be deprived since even by the Law there shall be guaranteed the protection of children from ill-treatments and various violence due to which there will be serious consequence (LFK, Article125, Gashi\&Aliu\&Vokshi, 2012, 289). If such actions are undertaken only to one of the children, then the parental right shall be deprived only to one child while when such actions are undertaken towards all children then the parental right shall be deprived for all children.

\section{Serious Violation of the Parental Right}

Parents shall be obliged to exercise the rights and obligations entitled to them in the general interest towards children. However, not in all cases, parents realize their rights and obligations in favour to the children. As a serious violation of the parental right may be considered any action by parents due to which there is endangered the health of children in cases 
when the juvenile is not provided with the medical assistance or he/she is not sent for medical treatment, when he/she is not provided with clothes, food, accommodation (Oruqi, 1994, 142, Aliu \& Gashi, 2007, 240 - 241), when there is no hygiene, no attention to the food (Alinčić \& Bakarić - Mihanović, 1980, 217). Hence, as causes due to existence of which there may be deprived the parental right shall be considered any action of the parents due to which there is endangered the health of children seriously. According to international framework, states should undertake respective measures to provide all children the respective necessary medical assistance and care for their health, by emphasizing the development of primary health care $(\mathrm{CRCH}$, Article $24(2, b))$. Furthermore, according to this framework there are regulated the matters of protection of children from use or sexual ill-treatment, trafficking for any purpose. This framework gives competence to the state that protects children from any form of use where there is endangered their welfare $(\mathrm{CRCH}$, Article $34(\mathrm{a}, \mathrm{b}$ and c), 35 and 36). Similarly, this matter is regulated even in Kosovo, where children enjoy protection from any job endangering or damaging their health, ill-treatment and sexual violence, use of psychotropic substances and drugs (FLK, Article 125 (5, 6 and 7$)$ ).

\section{The Rights and Obligation of Parents During the Period of Deprivation of Parental Right}

When the rights and obligations of parents are exercised to the prejudice of the interest of children, parents shall be deprived of parental right. By deprivation of parental right, parents can not exercise the rights and obligations towards their children, hence, parents can not exercise the rights related to the support, well-growing up, education and administration of the property of children (Podvorica, 2006, 198). In such circumstances when there is deprived the parental right, then the children shall be under the custody or they shall be trusted to third persons for care. However, even that the parents are deprived from the parental right, they shall not be deprived from all rights and obligations towards their children, so, they shall not be deprived from the right of support and necessary food for the children (FLK, Article 293. Gashi\&Aliu\&Vokshi, 2012, 605). Moreover, parents shall be obliged to fulfil expenses regarding the support, well growing up and education of children, when they are trusted to the third person for protection and education (Podvoriva, 2006, 198).

\section{Termination of Parental Responsibility}

Parental responsibility is not permanent and it terminates in certain circumstances. By the termination of parental responsibility, there shall be terminated the exercise of all rights and obligations towards their children. Theoretical treatments and legal framework recognize some cases of termination of parental responsibility. The parental responsibility may terminate by a) reaching the adulthood of the child, b) termination of parental responsibility, c) emancipation of the child and d) death of the parents or child (Aliu \& Gashi, 2007, 244).

a) Termination of parental right by reaching the adulthood of the child shall be when the child reaches the age of 18 and acquires the full ability to act and in this manner becomes fully capable to be bearer of the rights and obligations. It is important to mention that the termination of parental responsibility should not be understood as a sanction towards parents but as a natural circumstance which bring the termination of this responsibility.

b) Termination of continuous parental responsibility shall also comprise a circumstance based on which there shall be terminated the parental responsibility. After the termination of continuous parental responsibility parents shall not be responsible for their children since there are not anymore the circumstances that present the need the parents to take care after their children.

c) Adulthood shall mean the time when the individual becomes 18 years old and in this manner acquires the ability to act. However there are some cases when the ability to act may be acquired even before the individual reaches the age of 18 . In case when the minor of the age 16 and 18 gets married with the permission of the court, he/she acquires the full capability of acting which means he/she acquires his/her full emancipation. The term emancipation means the ability of a person to take decisions independently and to be bearer of the rights and obligations. Hence, in the cases of emancipation of the child there is terminated even the parental responsibility from which it is understood that parents are not responsible for their child since he/she is emancipated through the manner foreseen by the Law. Furthermore, the minor may acquire limited ability of action in those cases when from the age of fifteen concludes an employment relationship, he/she shall possess and administer by himself/herself the income from employment relationship (Aliu\& Gashi, 2007, 244). 
d) Termination of the parental responsibility upon the death of the parent or child - This is manner of termination of the parental responsibility by the action of nature when there occurs the death of the parent or the child. When one of these entities dies there shall terminate even the parental responsibility. Since the parental responsibility is of the personal character, in case of death of parents or child there cease to exist the rights and obligation of the parents towards their children either because of death of the parents or child.

In comparative aspects of the termination of parental responsibilities between Kosovo and other states of the region, it is important to mention that Kosovo and Albania have regulated in principle the termination of the parental responsibility. They have determined, by their Laws, that the parental responsibility shall terminate upon the reach of adulthood of the child (FLK, Article 128.2 and 154, FRSA, Article 216). It is important to emphasize that Kosovo and Albania have not determined, by their Laws, other manners of the termination of parental responsibility which are treated through the theory as the abovementioned states of the region have determined in their laws.

Other states of the region such as Croatia, Montenegro and Serbia have a more advanced and more comprehensive normative regulation in comparison to Kosovo and Albania since they, by their Laws, have determined expressively the manners of termination of parental responsibility upon the reach of adulthood of the child, emancipation of the child, upon the termination of continuation of parental responsibility as well as upon the death of the parents or the child (FLC, Article 119 and 120, FLMN, Article 95, FLS, Article 84).

Hence, the legal framework of these states has included cases that have been treated by the theory and there can easily be ascertained their regulatory superiority in comparison to the legal framework of Kosovo and Albania.

\section{Conclusion}

Based on the research of this paper, we have found that Parental Right shall mean the rights and obligations of the parents towards their children. The new legal framework regulates the parental right by constitutional and legal norms as well as by general legal acts.

From the comparative research there derives the fact that legal systems of the states of the region and beyond, regulate the matter of parents right by family Laws, while some other countries regulate this matter by civil codes.

Other research in this paper presents that the national legal framework has established norms which have regulated very well the matter of limitation of parental responsibility.

From the analysis between applicable legislation in Kosovo with the legislations of states of the region, regarding the limitation of parental responsibility and causes of limitation of that responsibility we find that parents can not be limited to actions by which there can be violated the general interests of children and endangered their welfare. According to legislation in Kosovo the parental right shall be limited when parents behave in irresponsible way, abuse the parental right and endanger the rights and interests of children. However, lawmaker in Kosovo has, with the purpose of protection of interests of children, determined the causes of limitation of parental right and has determined the mechanisms of supervision of exercise of those rights. It is important to emphasize that a similar regulation regarding the limitation of parental right is determined even by the legal framework of states of the region except Albania.

Object of normative regulation of legal framework of Kosovo shall be even the deprivation of parental right. According to legal framework in Kosovo the parental right may be deprived when the parents misuse and present carelessness while exercising the parental right. Moreover the legal comparative treatment of the deprivation of this right indicates that even the legal systems of the states of the region have similarities with Kosovo regarding the legal normative regulation on deprivation of parental responsibility but there are some differences regarding the determination of entities on initiation of procedure for deprivation of this right.

Study object in this paper has also been the matter of normative regulation of termination of parental responsibility. Regarding this, it is important to emphasize that there are great differences in normative regulation between Kosovo and states of the region. Kosovo has only determined in principle that the parental responsibility terminates upon the reach of adulthood of the child, where there is a lack of determination of other cases of termination of parental responsibility. The same regulation as Kosovo there is in Albania where there has been determined completely similarly that the parental responsibility terminates upon the reach of adulthood, however this regulation is rather shallow knowing that there are 
other cases by which the parental responsibility terminates which have not been foreseen by Kosovo and Albania Laws. However, the abovementioned states have a more comprehensive determination regarding the normative determination of termination of parental responsibility. Croatia, Serbia and Montenegro in their family Laws have expressively determined that parental responsibility shall terminate upon the reach of adulthood of the child, emancipation of the child, upon termination of continuation of parental responsibility, upon death of parents or child.

In comparative treatments of legal framework of Kosovo with the frameworks of legal systems of mentioned states we find that the matter of termination of parental responsibility shall be regulated in a more advanced and detailed manner from the above-mentioned states of region, as well as it would be important to be taken into consideration these determinations when amending and supplementing the legislation of Kosovo and Albania and to be incorporated the mentioned cases in order that there shall be eliminated the legal gaps that actually exist within legal norms of Kosovo and Albania.

These brief conclusions present our views of a legal framework regarding the organic manner that refers to a spectre of problems, matters, concepts and legal solutions on the parental right within the legal system of Kosovo and other legal systems that have been treated in this paper. Treatment of normative aspect of regulating the parental right in the view of formal expression of legal normative regulation of the states of region consequently brings into incontestable conclusion the existing of common and distinctive characteristics in normative regulation of parental right.

\section{Abbreviations}

$\mathrm{CRCH}-$ Convention on the Rights of the Child,

FLK - Family Law of Kosovo,

FCRA - Family Code in the Republic of Albania,

FLC - Family Law in Croatia,

FLM - Family Law in Montenegro,

FLS - Family Law in Serbia,

LFRM - Law on Family in the Republic of Macedonia

GCC - German Civil Code

LOCP - Law on out-contentious procedure

LPADV - Law on Protection against Domestic Violence

\section{Literature}

- Podvorica. H (2006), E Drejta Familjare (The Family Right), Prishtina

- Aliu, A \& Gashi. H (2007), E Drejta Familjare (The Family Right), Prishtina

- Oruqi. G, (1994), E Drejta Familjare (The Family Right), Prishtina,

- Begeja. S, E Drejta Familjare ne Shqipëri (The Family Right of Albania), Tirana

- Stark B (2005), International Family Law,

- Garber.B (2010) Developmental Psychology For Family Law Professionals, Theory, Application and the Best Interests Of The Child, 2010

- Brown.T \& Alexander.R,(2007) Child Abuse and Family Law,

- Alinčić. M \& Bakarić - Mihanović. A , (1980), Porodicno Pravo, Zagreb

- Convention on the Rights of the Child, 
- Gashi.H \& Aliu,A \& Vokshi.A, (2012) Komentari i Ligjit të Familjes në Kosovë (Commentary of the Family Law of Kosovo), Prishtina

- European Convention on Human Rights, Protocol No. 7, Strasbourg 22. 11. 1984

- Family Law of Kosovo No. 2004 / 32,

- Law on out-contentious procedure, No. $03 / \mathrm{L}-007$

- Law on Protection against Domestic Violence, No. $03 / \mathrm{L}-182$

- Family Law in Croatia, No. 01-081-03-2596/2,

- Family Code in the Republic of Albania, No. 9062,

- Family Law in Montenegro No. 01-626/14,

- Family Law in Serbia, 2006,

- Law on Family in the Republic of Macedonia, 1993 